Research Journal of Biological Sciences 7 (8): 297-301, 2012

ISSN: $1815-8846$

(C) Medwell Journals, 2012

\title{
Fungal Diseases of Olive Cuttings in the Rooting Stage in Jordan
}

\author{
Mahmoud Al-Khatib \\ Department of Plant Production, Faculty of Science, \\ Jerash University, 26150 Jerash, Jordan
}

\begin{abstract}
Several olive nurseries in Jordan were surveyed for basal and root rot fungi in olive cuttings during the rooting stage in Summer and Autumn 2011. Causal agents were isolated from symptomatic olive cuttings on PDA and identified according to specific keys. The most frequently isolated fungi were Pythium aphanidermatum followed by Fusarium solani, Rhizoctonia solani and Verticllium dahlia. Pathogenicity tests showed variation in the disease incidence caused by the isolated fungi on olive cuttings from different olive varieties. The highest disease incidence was caused by the fungus $P$. aphanidermatum on raseei olive variety (47\%) were on other olive varieties, incidence ranged between 21 and $26 \%$. The disease incidence caused by each of the other isolated fungi ranged from $11-15 \%$ on the different tested olive varieties. Var., raseei was the most affected by both $P$. aphanidermatum (47\%) and composite sample (68\%). Analysis of variance showed significant effects of nabali olive variety on disease incidence for the different fungal isolates.
\end{abstract}

Key words: Olive, rot, pathogenic, fungi, Jordan

\section{INTRODUCTION}

Olive (Olea europea) is an evergreen tree native to the Mediterranean region (Tous and Ferguson, 1996) which includes about $95 \%$ of the world olive orchards and $>95 \%$ of the olive oil and $75 \%$ of the table olives production (Fabbri et al., 2004). The total plantation area of olive all over the world exceeds 10 million ha (FAO, 2010). In Jordan, olive ranks the first grown fruit crop due to its adaptability to a wide range of climatic and soil conditions. El-Habbab (2006) studied the distribution of olive trees in Jordan and pointed that they are found almost all over the kingdom from the high lands to the Jordan valley and the desert region (Fig. 1). The total area planted with olive trees was about 601400 dunum with a total number of trees exceeding 11154000 tree, producing about 140720 ton and representing $74 \%$ of the total area planted with fruit trees in Jordan. Olive trees are mainly propagated in Jordan as in many other countries of the world by self-rooted cuttings which is the most popular vegetative propagation technique (Ayoub and Qrunfleh, 2006). More than 45 nurseries in Jordan produce about 2 million rooted olive cuttings yearly (Anonymous, 2010a).

One of the best propagation techniques of olive trees is by the use of semi-hard wood cuttings because many cuttings can be obtained from one tree and semi-hard wood cuttings develop roots better than the other kinds of cuttings (Hartmann and Kester, 1975).

Propagation conditions are characterized by high humidity about $80-90 \%$ and moderate to relatively high

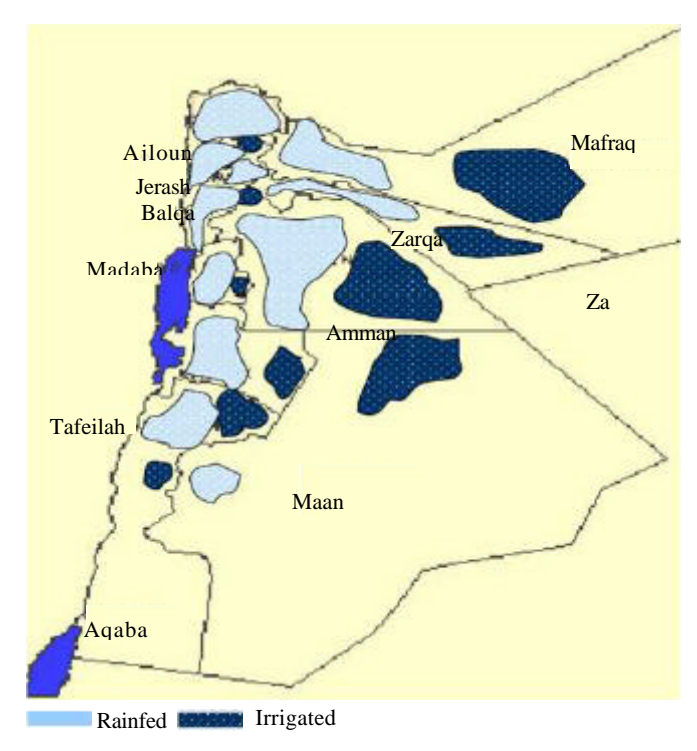

Fig. 1: Olive producing regions in Jordan (El-Habbab, 2006)

temperature about $28-35^{\circ} \mathrm{C}$ for a long period of time exceeding 60 days (Hartmann et al., 1997). These conditions are favorable for most fungal pathogens that affect and damage olive cuttings in the rooting stage (Martelli, 1999). It was found that in many olive propagating nurseries including those related to the Ministry of Agriculture in Jordan. Olive cuttings are subjected to a variety of fungal pathogens. Fungal diseases may cause rot and death of $15-50 \%$ of the 
cuttings in the rooting stage (Anonymous, 2010b). Therefore, this research was conducted to record the main fungal pathogens that affect olive cuttings in the rooting stage in Jordan and the response of different olive varieties to these fungi.

\section{MATERIALS AND METHODS}

Isolate collection: Diseased and symptomatic olive cuttings were collected from 15 olive propagating nurseries from both public and private sectors in Jordan during Summer and Autumn 2011. Cuttings were washed with running tab water and cut into small pieces $0.5 \mathrm{~cm}$ long. Infected pieces were surface sterilized with $0.5 \%$ sodium hypochloride $(\mathrm{NaOCl})$ for $1 \mathrm{~min}$ and plated on Potato Dextrose Agar media (PDA). Plates were incubated at $25 \pm 2^{\circ} \mathrm{C}$ for 7 days. Cultures were morphologically and microscopically studied to determine the causal agents.

Plant material: Semi-hard wood olive cuttings of different varieties (Raseei, nabali, grosadi, manzanillo and nasouhi) were obtained from al-Hussein Agricultural Station and al-Faisal nursery (Ministry of Agriculture). They were prepared for rooting in inoculated perlite media under greenhouse conditions in early Summer (June, 2012).

Plant infection and pathogenicity tests: Fungal suspensions from 1 week old cultures were prepared and adjusted to $10^{6}$ conidia $\mathrm{mL}^{-1}$ using hemacytometer. The prepared inoculums were used to infest the rooting media by applying $30 \mathrm{~mL}$ of the fungal suspension to each $1 \mathrm{~kg}$ of the rooting media which consists of perlite only, then cuttings were treated with the rooting hormone Indole Butyric Acid (IBA 6000 ppm) and planted in the infested rooting media under green house conditions. Cuttings were irrigated by mist irrigation method (Mousa et al., 2006; Sghir et al., 2005). About 100 cuttings from each variety were planted in 5 pots (20 cuttings for each treatment and 1 pot as control) for each of the isolated fungi and 1 treatment with 4 replicates for a composite sample of all isolated fungi. Air temperature during the experiment fluctuated between 32 and $18^{\circ} \mathrm{C}$ where humidity was around $80 \%$ during the 1 st 6 weeks of the experiment (Fabbri et al., 2004). Re-isolation of the pathogenic fungi was conducted to ensure the association of fungal isolates with the developed disease.

Disease assessment: Disease incidence was recorded 10 weeks after inoculation (planting in the inoculated perlite media). Dead cuttings and those showing rot symptoms in their basal part were considered as infected ones and their percentage was calculated for each olive variety and for each fungal pathogen.

Statistical analysis: All treatments were arranged in Randomized Complete Block Sesign (RCBD) with 4 replicates for each treatment. General Linear (GLM) ANOVA (SPSS Ver.10) was used to find differences $(\mathrm{p} \leq 0.05)$ between treatment means and control.

\section{RESULTS}

Isolation and identification of rot fungi: In all surveyed nurseries basal and root rot disease was observed on all olive varieties with different ratios. Disease symptoms appeared as leaf roll and yellowing on the upper part of the cuttings followed by leaf dropping, rot and discoloration of the basal part of the cuttings and absence of roots in the diseased cuttings. Figure 2 shows propagation plots, healthy cuttings and infected ones 10 weeks after planting.

A total of 45 isolate were collected from the different surveyed nurseries. Isolates were identified according to their morphological and microscopical characters using specific keys for each fungus. Barnett and Hunter (1987) for imperfect fungi, Booth (1971) for Fusarium, Sneh et al. (1991) for Rhizoctonia and Dick (1989) for Pythium. Isolated fungi and Fungal-Like Organisms (FLO) were defined as Fusarium solani, Pythium aphanidermatum, Rhizoctonia solani and Verticillium dahlia.

The disease incidence varied between $15 \%$ in grosadi variety and $33 \%$ in raseei. In most cases $>1$ fungal pathogen was isolated from infected cuttings but the (FLO) Pythium was isolated from all diseased cuttings. Pathogens isolated from diseased olive cuttings and disease incidence are shown in Table 1.

Pathogenicity tests showed that the different fungi and FLO isolated from diseased cuttings varied in their aggressiveness on each of the used olive varieties. The FLO $P$. aphanidermatum was found to be the most aggressive and caused the maximum damage on olive cuttings where other fungi were found to cause less damage as shown in Table 2. Cuttings planted in rooting media infested with a composite sample of fungi showed higher percentage of decline (disease incidence) in all

Table 1: Fungal and FLO pathogens isolated from diseased olive cuttings according to olive varieties

\begin{tabular}{llc}
\hline Variety & Fungal pathogens and FLO & Disease incidence $(\%)$ \\
\hline Nabali & $\begin{array}{l}\text { Fusarium soloni, Pythium } \\
\text { ophonidermatum, Verticillium dahlice }\end{array}$ & $25^{\mathrm{c}^{*}}$ \\
Raseei & $\begin{array}{l}\text { Fusarium soloni, Pythium } \\
\text { ophonidermatum, Rhizoctonia soloni }\end{array}$ & $33^{\mathrm{d}}$ \\
Grosadi & Pythium cohonidermatum, Rhizoctonia soloni & $15^{\mathrm{a}}$ \\
Nasouhi & Fusarium solani, Pythium ophonidermatum & $17^{\mathrm{a}}$ \\
Manzanillo Fusarium solani, Pythium ophonidermatum & $22^{\mathrm{b}}$ \\
\hline $\begin{array}{l}\text { Numbers followed by different symbols within column } 3 \text { are significantly } \\
\text { different }\end{array}$
\end{tabular}


Res. J. Biol. Sci., 7 (8): 297-301, 2012

Table 2: Disease incidence of different fungal and FLO pathogens on olive cuttings in the rooting stage 10 weeks after inoculation

\begin{tabular}{lcccccc}
\hline Isolate & \multicolumn{1}{c}{} & \multicolumn{4}{c}{ Composite } \\
variety & Pythium & Fusarium & Rhizoctonia & Verticillium & fungi & Control \\
\hline Nabali & $29^{b^{*}}$ & $17^{\mathrm{a}}$ & $19^{\mathrm{b}}$ & $19^{\mathrm{b}}$ & $42^{\mathrm{b}}$ & $13^{\mathrm{d}}$ \\
Raseei & $47^{\mathrm{a}}$ & $19^{\mathrm{a}}$ & $15^{\mathrm{a}}$ & $16^{\mathrm{a}}$ & $68^{\mathrm{d}}$ & $5^{\mathrm{a}}$ \\
Grosadi & $28^{\mathrm{b}}$ & $17^{\mathrm{a}}$ & $17^{\mathrm{ab}}$ & $15^{\mathrm{a}}$ & $41^{\mathrm{b}}$ & $8^{\mathrm{b}}$ \\
Nasouhi & $28^{\mathrm{b}}$ & $20^{\mathrm{a}}$ & $18^{\mathrm{ab}}$ & $15^{\mathrm{a}}$ & $45^{\mathrm{c}}$ & $9^{\mathrm{b}}$ \\
Manzanillo & $21^{\mathrm{a}}$ & $19^{\mathrm{a}}$ & $17^{\mathrm{bb}}$ & $14^{\mathrm{a}}$ & $32^{\mathrm{a}}$ & $8^{\mathrm{b}}$ \\
\hline
\end{tabular}

Numbers followed by different symbols within columns are significantly different
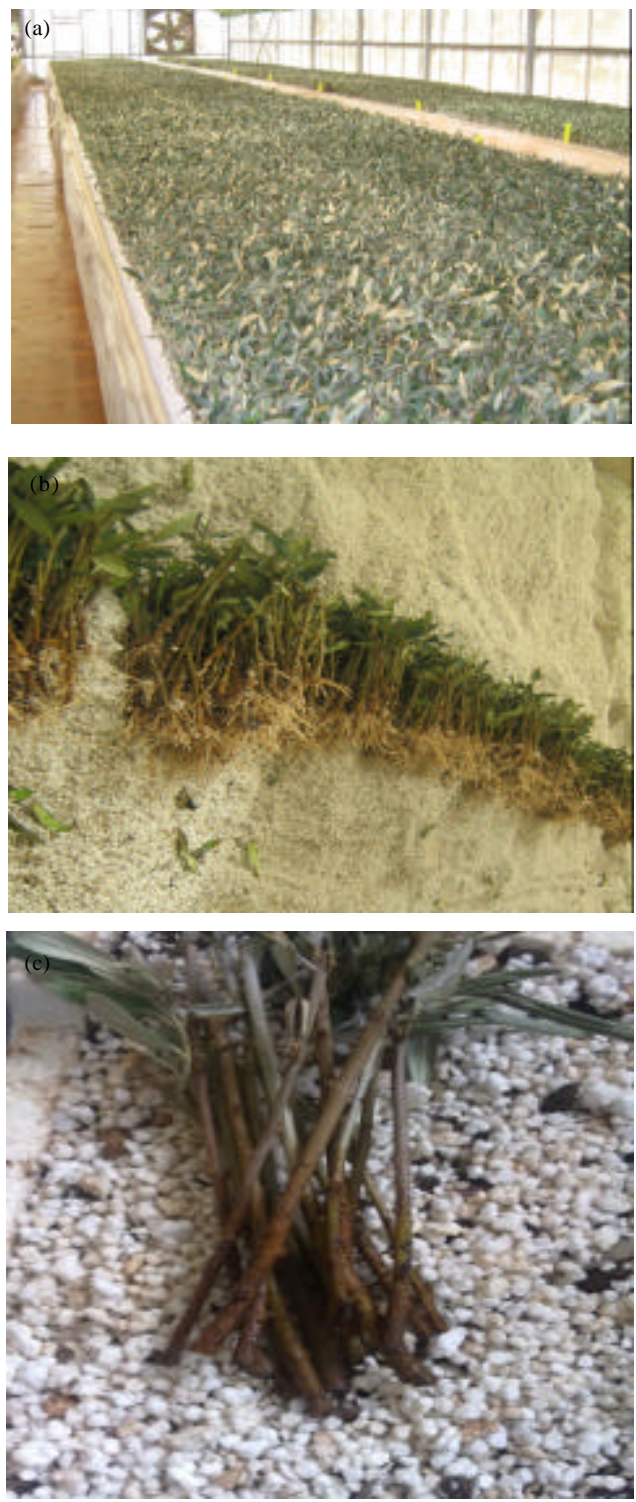

Fig. 2: Propagation plots, healthy rooted cuttings and infected cuttings 10 weeks after inoculation: a) Propagation plots; b) Healthy rooted cuttings; c) Infected cuttings
Table 3: Response of different olive cultivars in the rooting stage to fungal pathogens expressed as number of dead cuttings 10 weeks after inoculation

\begin{tabular}{lccccc}
\hline $\begin{array}{l}\text { Olive var. } \\
\text { Fungal isolates }\end{array}$ & Nabali & Raseei & Grosadi & Nasouhi & Manzanillo \\
\hline Pythium & $25^{\mathrm{b}}$ & $47^{\mathrm{c}}$ & $26^{\mathrm{c}}$ & $24^{\mathrm{c}}$ & $21^{\mathrm{c}}$ \\
Fusarium & $14^{\mathrm{a}}$ & $12^{\mathrm{b}}$ & $12^{\mathrm{b}}$ & $13^{\mathrm{b}}$ & $13^{\mathrm{b}}$ \\
Rhizoctonia & $15^{\mathrm{a}}$ & $13^{\mathrm{b}}$ & $13^{\mathrm{b}}$ & $14^{\mathrm{b}}$ & $13^{\mathrm{b}}$ \\
Verticillium & $15^{\mathrm{a}}$ & $12^{\mathrm{b}}$ & $11^{\mathrm{b}}$ & $12^{\mathrm{b}}$ & $11^{\mathrm{ab}}$ \\
Composite fungi & $42^{\mathrm{c}}$ & $68^{\mathrm{d}}$ & $41^{\mathrm{d}}$ & $45^{\mathrm{d}}$ & $32^{\mathrm{d}}$ \\
Control & $13^{\mathrm{a}}$ & $8^{\mathrm{a}}$ & $8^{\mathrm{a}}$ & $9^{\mathrm{a}}$ & $8^{\mathrm{a}}$ \\
\hline
\end{tabular}

Numbers followed by different symbols within columns are significantly different

olive varieties compared with those infected with each of the isolated fungi singularly. Disease incidence is expressed as the percentage of dead plants estimated 10 weeks after inoculation.

On the other hand, pathogenicity tests indicated that different olive varieties were found to vary in their response to the different isolated fungi and FLO as shown in Table 3.

Some olive cuttings failed in forming root system within 10 weeks but were still healthy without any discoloration or rot symptoms. These cuttings were considered as healthy ones and were not included in the disease incidence calculations.

\section{DISCUSSION}

This is the first study of root rot fungal and fungal-like organisms of nursery olive cuttings in the Hashemite Kingdom of Jordan. Results of this study revealed the effect of these organisms on nursery olive cuttings and the response of different olive varieties grown in Jordan to these organisms. The main causal of basal and root rot of olive cuttings in all olive varieties was $P$. aphanidermatum which is a FLO (Oomycetes). $P$. aphanidermatum was isolated from all diseased olive cuttings from different nurseries and was found to be the main causal agent of decline in nursery olive cuttings during the rooting stage. Disease incidence related to $P$. aphanidermatum was significantly different from that caused by all other organisms. These results were confirmed by Agrios (2005) who pointed that Pythium is one of the most common and most important causes of seed rot, seedling damping-off and root rot of all types of plants.

The other root rot fungi isolated were $F$. solani and Rhizoctonia solani. No significancy between the two fungi on the different olive varieties was recorded. $F$. solani is a necrotrophic soil-borne plant pathogenic fungus that causes root and stem rots accompanied by the production of mycotoxins of different host plants. It is highly affected by $\mathrm{pH}$ and its severity increases by applying ammonium fertilizers (Huber and Watson, 1974), 
this explains the low effect of the fungus on nursery olive cuttings where the $\mathrm{pH}$ does not exceed 5.6 in rooting media.

The results also indicated low effect of the fungus Rhizoctonia solani on nursery olive cuttings under green house conditions. The biology of Rhizoctonia and effect of various crop establishment methods on the fungus were studied by Burpee and Martin, (1992) and Willocquet et al. (2000). They pointed that Rhizoctonia solani affects several vegetables and fruit trees and causes damping-off disease but mainly in cold wet soils which is in agreement with the results since olive cuttings were planted under green house conditions with temperature ranging between 18 and $32^{\circ} \mathrm{C}$.

The fungus Verticillium dahlia is well defined as vascular wilt fungus and affects the vascular bundles in the stem of its host plants (Vossen et al., 2008). It attacks $>200$ species of plants and favored by cool moist soils (Ferguson et al., 2008), this conferms the results which indicates limited effect of the fungus on nursery olive cuttings under green house conditions. Al-Khatib (1999) studied wilt and root rot fungi of stone-fruit nursery stocks in Jordan and documented that Fusarium, Pythium, Rhizoctonia, Verticillium and Phytophthora were the main root rot fungi in different fruit trees and dispersed in different fields in Jordan. Most stone-fruit fields especially in rain-fed areas in Jordan are converted to olive field after decline of stone-fruit fields due to infection by Capnodes temperionis. Therefore, root rot fungi were transmitted to olive orchards and spread in different nurseries in the country.

The results showed also variation in olive varieties response to different pathogenic organisms under green house conditions. This was in agreement with previous studies. Mousa et al. (2006) studied the response of different olive varieties to root rot diseases and found that both varieties manzanillo and picual varieties were more affected than coratina variety. Sanei and Razavi (2012) studied olive fungal diseases in north of Iran, their results showed significant variation in the different olive varieties to the different studied causal agents. Therefore, it is well documented that different olive varieties vary in their response to different pathogenic fungi in field and under green house conditions with which our results are in agreement.

\section{CONCLUSION}

Inoculating olive cuttings with a composite sample consisting of a mixture of pathogenic fungi and FLO, resulted in a synergistic effect on the inoculated olive cuttings and caused catastrophic disease incidence ranging between 32 and $68 \%$ under green house conditions. More disease incidence is expected in the field when infected rooted cuttings are transplanted. This was assured by Sanei and Razavi (2012) in Iran, Mousa et al. (2006) in Egypt and Al-Ibrahem (2006) in Syria.

\section{REFERENCES}

Agrios, G.N., 2005. Plant Pathology. 5th Edn., Academic Press, New York, USA., ISBN: 13-9780120445653, Pages 922 .

Al-Ibrahem, A., 2006. Olive oil sector in Syria: The present status and prespective. Proceedings of the 2nd Olive Bioteq International Seminar-Recent Advances in Olive Industry-Special Seminars and Invited Lectures, November 5-10, 2006, Italy, pp: 97-108.

Al-Khatib, 1999. Study of wilt and root rot fungi of stone-fruit nursery stocks in Jordan and their control. M.Sc. Thesis, University of Jordan. Amman, Jordan.

Anonymous, 2010a. Annual agricultural statistics. The Hashemite Kingdom of Jordan, Department of Statistics.

Anonymous, 2010b. Annual report, ministry of agriculture, department of agricultural economy. The Hashemite Kingdom of Jordan.

Ayoub, S.J. and M.M. Qrunfleh, 2006. Anatomical aspects of rooting Nabali and Raseei olive semi-hardwood stem cuttings. Jordan J. Agric. Sci., 2: 16-28.

Barnett, H.L. and B.B. Hunter, 1987. Illustrated Genera of Imperfect Fungi. 4th Edn., MacMillan Publishing Company, New York, USA.

Booth, C., 1971. The Genus Fusarium. Commenwealth Mycological Institute, Kew, Surrey, England, Pages: 237.

Burpee, L. and B. Martin, 1992. Biology of Rhizoctonia species associated with turfgrasses. Plant Dis., 76: 112-117.

Dick, M.W., 1989. Keys to Pythium. Reading University Press, UK.

El-Habbab, M.S., 2006. Introducing organic farming system in olive production and linking small farmers to markets: A Success Story. Ministry of Agriculture, Annual Agricultural Statistics, Amman, Jordan.

FAO, 2010. Agro-Maps: A Global Spatial Database of Subnational Agricultural Land-Use Statistics. Food and Agriculture Organization, Italy.

Fabbri, A., G. Bartolini, M. Lambardi and S. Kailis, 2004. Olive Propagation Manual. Landlinks Press, Collingwood, Australia, ISBN: 13-9780643099388, Pages: 160.

Ferguson, F., P. M. Vossen and B.L. Teviotdale, 2008. UC IPM Pest management guidelines: Olive diseases. UCANR Publication 3452. 
Hartmann, H.T. and D.E. Kester, 1975. Anatomical and Physiological Basis of Propagation by Cuttings. In: Plant Propagation Principles and Practices, Hartmann, H.T. and D.E. Kester (Eds.). 3rd Edn., Prentice-Hall Inc., Englewood cliffs, New Jersey, USA.

Hartmann, H.T., D.E. Kester and R. Geneve, 1997. The Biology of Propagation by Cuttings. In: Plant Propagation Principles and Practices, Hartmann, H.T., D.E. Kester, F. Davies and R. Geneve (Eds.). 6th Edn., Prentice-Hall Inc., USA .

Huber, D.M. and R.D. Watson, 1974. Nitrogen form and plant disease. Ann. Rev. Phytopathol., 12: 139-165.

Martelli, G.P., 1999. Infectious diseases and certification of olive: An overview. EPPO Bull., 29: 127-133.

Mousa, M.S., M.K. Ali, A.A. Mosa and I.S. Elewa, 2006. Root rot disease of olive transplants and its biological control. Arab Univ. J. Agric. Sci., 14: 395-409.

Sanei, S.J. and S.E. Razavi, 2012. Survey of olive fungal disease in North of Iran. Ann. Rev. Res. Biol., 2: 27-36.
Sghir, S., P. Chatelet, N. Ouazzani, F. Dosba and I. Belkoura, 2005. Micropropagation of eight Moroccan and French olive cultivars. Hortscience, 40: 193-196.

Sneh, B., L. Burpee and A. Ogoshi, 1991. Identification of Rhizoctonia species. APS Press, St. Paul, MN.

Tous, J. and L. Ferguson, 1996. Mediterranean Fruits. In: Progress in New Crops, Janick, J. (Ed.). ASHS Press, Arlington, VA., pp: 416-430.

Vossen, P., D. Gubler and M.A. Blanco, 2008. Vertcillium wilt of olive. University of California Cooperative Extension. Newsletter of Olive Oil Production and Evaluation, Volume 3, Number 4, pp: $1-4$.

Willocquet, L., L. Fernandez and S. Savary, 2000. Effect of various crop establishment methods practiced by Asian Farmers on epidemics of rice sheath blight caused by Rhizoctonia solani. Plant Pathol., 49: 346-354. 